\title{
Assessment of awareness regarding right to food and food security schemes and evaluation of success of mid day meal programme in selected schools of Ajmer city (Rajasthan)
}

\author{
Ritu Mathur and Swati Mathur
}

\begin{abstract}
Right to food is a Human Right, protecting the right for people to feed themselves in dignity, implying that sufficient food is available and people have means to it, access to it, and it meets the individual's dietary needs (United Nations Declaration of Human Rights, 1948). To ensure the availability of food to all, various schemes like Targeted Public Distribution Scheme which focuses on Below Poverty Line families, Antyodaya Anna Yojana for the poorest of poor, Annapurna Scheme targeted towards citizens of the age of 65 and above are being run by the Government of India. Besides these The Mid Day Meal Programme, a Nutrition Programme which is focussed to attract more children to Schools and improve their nutritional status are also being executed by the Government of India. The present study was undertaken on a random sample of 30 subjects from both Below Poverty line and Above Poverty Line families of Ajmer city, to find the awareness in people about the Right to Food and Food Security Schemes. Information regarding the success of Mid Day Meal Programme was obtained by a survey done in 10 Schools of Ajmer. To conduct the research, a Questionnaire was framed with questions related to awareness regarding the Right to Food and Food Security Schemes. The questions also included those related to income, interval of buying ration, palatability of Food Grains. The results revealed that 63 per cent of the people were aware of the Right to Food as their basic right while the remaining 36 per cent were unaware. The Targeted Public Distribution Scheme was very popular amongst people. This can be said as 90 per cent of the subjects were aware of it and many were availing its benefits. The Antyodaya Anna Yojana was relatively less popular and only about 60 per cent of the subjects knew of such a Scheme being executed by the Government of India. Almost similar is the case with the Annapurna Scheme as only a percentage of 40 per cent reflected any awareness in reference to it. The National Food Security Act is the least popular and in the study, a mere 30 per cent subjects answered positively towards it.Concerning the Mid Day Meal Scheme, the study revealed that it provided adequate nutrition to children of classes 1 to 5, but was found to be inadequate in terms of nutritive value (calories)for chlidren of classes VI toVIII.The meals provided did not meet the hygiene standards too.
\end{abstract}

Key Words : Right to food, Food security schemes, Mid day meal programme, Targeted public distribution system, Antyodaya anna yojana, Annapurna scheme, Food security act.

\section{MEMBERS OF RESEARCH FORUM}

Author for correspondence :

RITU MATHUR, Department of Food Science and Nutrition, M.D.S. University, AJMER (RAJASTHAN) INDIA

Eamil : drritumathur@gmail.com

Associate Authors' :

SWATI MATHUR, Department of Food Science and Nutrition, M.D.S. University, AJMER (RAJASTHAN) INDIA
How to cite this article : Mathur, Ritu and Mathur, Swati (2015). Assessment of awareness regarding right to food and food security schemes and evaluation of success of mid day meal programme in selected schools of Ajmer city (Rajasthan). Food Sci. Res. J., 6(2): 251-257. 